\title{
ENVIRONMENTAL WATER QUALITY ASSESSMENT IN GUARATUBA BAY, STATE OF PARANÁ, SOUTHERN BRAZIL
}

\author{
Byanka Damian Mizerkowski ${ }^{1,2,{ }^{*},}$ Eunice da Costa Machado ${ }^{l}$, Nilva Brandini ${ }^{l}$, \\ Mariana Gallucci Nazario ${ }^{l}$ and Kleber Vieira Bonfim ${ }^{l}$ \\ Universidade Federal do Paraná - Centro de Estudos do Mar \\ (Av. Beira Mar, s/n, 83255-276 Pontal do Sul, PR, Brasil) \\ Helmholtz Centre Geesthacht - Centre for Material and Coastal Research. \\ (Max-Planck-Str. 1, 21502, Geesthacht, Germany) \\ *Corresponding author: byanka_dm@yahoo.com.br
}

\begin{abstract}
A B S T R A C T
An environmental assessment of the estuarine waters of Guaratuba bay, Paraná State, Brazil, is provided through the analysis of physical-chemical, biological and hydrographic dynamics. Twelve stations with a bi-monthly frequency (from October/2002 until August/2003) were sampled during spring and neap tides for the determination of $\mathrm{pH}$, Secchi depth, $\mathrm{CO}_{2}$ saturation, dissolved oxygen, chlorophyll, suspended particulate matter and dissolved inorganic nutrients (nitrate, nitrite, ammonium, phosphate and silicate). Based on the evaluation of six parameters (chlorophyll, Secchi depth, $\mathrm{CO}_{2}$ saturation, dissolved inorganic nitrogen and phosphorus and dissolved oxygen), Guaratuba Bay shows a low to medium trophic status, i.e. from meso- to oligotrophic, and a predominant heterotrophic metabolism, meaning that respiration overcomes primary production. Horizontal stratification was observed during the rainy season, while during the dry season the system showed more homogeneous conditions. Inorganic and/or organic matter in Guaratuba Bay seem to be controlled mainly by the seasonality of precipitation and/ also by ebb and flood tidal phase variations.
\end{abstract}

\section{RESUMO}

A dinâmica das variáveis físico-químicas, biológicas e hidrográficas, em escalas temporal e espacial, sua variabilidade e tendências, permite avaliar a qualidade ambiental de estuários. Esse trabalho descreve as flutuações da qualidade de água da Baía de Guaratuba, sul do Estado do Paraná. Foram amostrados doze pontos em campanhas bimensais (outubro/2002 a agosto/2003), em situação de sizígia e de quadratura, para a análise das variáveis $\mathrm{pH}$, transparência, saturação de $\mathrm{CO}_{2}$, oxigênio dissolvido, clorofila-a, material particulado em suspensão e nutrientes inorgânicos dissolvidos (nitrato, nitrito, amônio, fosfato e silicato). Considerando as seis variáveis descritoras da qualidade de água (clorofila-a, profundidade de Secchi, saturação de $\mathrm{CO}_{2}$, fósforo e nitrogênio inorgânicos dissolvidos e oxigênio dissolvido), observou-se que a Baía apresentou estado trófico médio para baixo, i.e. de meso para oligotrófico, e que o seu metabolismo é predominantemente heterotrófico, ou seja, os processos de respiração superam os de produção. Foi verificada uma maior estratificação horizontal durante o período chuvoso e características relativamente mais homogêneas durante a estação mais seca. A qualidade da água na baía de Guaratuba parece ser controlada mais pelos aportes de material inorgânico e/ou orgânico associados a pluviosidade e/ou por variações com as fases de maré vazante e enchente.

Descriptors: Water quality, Hydrodynamics, Nutrients, Spatial and temporal variation, Guaratuba Bay.

Descritores: Qualidade de água, Hidrodinâmica, Nutrientes, Variação espaço-temporal, Baía de Guaratuba.

\section{INTRODUCTION}

Eutrophication is an important issue that has become a worldwide problem over recent decades (CLOERN, 2001; OSPAR, 2001; BRICKER et al.,
2003). Eutrophication can impact coastal waters negatively, and the evaluation of water quality on appropriate spatial and temporal scales is necessary to understand the complex interactions between non- 
biological and biological features and the carrying capacity of estuaries.

The State of Paraná, southern Brazil, has two main estuarine systems: the Paranaguá Estuarine System and Guaratuba Bay. Guaratuba Bay (Fig. 1) is a system located on the southern coast of Paraná, with around 32,000 inhabitants, and is inserted in the Environmental Protection Area of Guaratuba (APA Guaratuba).

Economic activities are based on tourism, recreation, small scale fisheries and aquaculture. Over the past three decades, Guaratuba Bay has been under increasing urban pressure following the regional development trends but still remains relatively pristine, with extensive mangrove coverage along the margins representing an important nursery and feeding environment for various species (CHAVES; BOUCHEREAU, 2000). Besides tourism and recreational attractions, activities such as small-scale fisheries, aquaculture and proposals for hydroelectric power plants in the catchment area demand a better understanding of the functioning of the estuarine system and so far no information is available about the nutrient and phytoplanktonic fluctuations in Guaratuba Bay.

Environmental protection and the activities undertaken within the area comprehended by the system may generate conflict. For example, the population living on the shores of the system can increase by up to $300 \%$ during summer whereas sewage treatment plants cover only $30 \%$ of the permanent population. Moreover, the quality of the shellfish produced by the aquaculture farms also demands good quality water that can suffer the impact of sewage pollution. Thus the water quality of Guaratuba Bay was assessed in order to investigate spatial-temporal chlorophyll concentrations (as indicator of phytoplanktonic biomass), total phosphorus and nitrogen and inorganic nutrient fluctuations in relation to environmental descriptors. This information should justify the legal guidelines and standards for the protection of the environment and the regulation of human activities.

\section{Material ANd Methods}

Study Area

Guaratuba Bay (Fig. 1) is located around the coordinates $25^{\circ} 51.8^{\prime} \mathrm{S}$ and $48^{\circ} 38.2^{\prime} \mathrm{W}$ having a surface water area of $50.19 \mathrm{~km}^{2}$ and a mean depth of 3 $\mathrm{m}$. Around $24 \%$ of the bay is shallow, the maximum depth of $27 \mathrm{~m}$ being observed at the system's mouth (MARONE et al., 2004) which is formed by two rocky points $500 \mathrm{~m}$ apart. From its connection with the Atlantic Ocean, the system widens inwards for $15 \mathrm{~km}$, harboring many sand banks.
The bay receives most of its freshwater inflow from two rivers, the Cubatão and the São João, which contribute with the larger part of the surrounding area's freshwater runoff, which attains up to $80 \mathrm{~m}^{3} / \mathrm{s}$. Guaratuba Bay is surrounded by seagrass and mangrove vegetation, which are more extensive along the northern margin of the estuary, whereas its southern margin is largely occupied by urban settlements and agricultural enterprises (MARONE et al., 2004).

The hydrodynamic scenario of Guaratuba Bay is presented by Marone et al. (2004). The system has strong currents (more than $2 \mathrm{~m} \mathrm{~s}^{-1}$ at the mouth), and semi-diurnal tides of up to $1.5 \mathrm{~m}$ range $(0.65 \mathrm{~m}$ at neap tide). In a complex tide propagation pattern (progressive, mixed and stationary), up to $75.10^{6} \mathrm{~m}^{3}$ of water are transported by the spring tides and $32.10^{6} \mathrm{~m}^{3}$ at the neap ones. In situations of neap tides and low river runoff, strong vertical stratification is to be observed due to the intensification of the baroclinic component of the pressure gradient.

The climate of this region is classified as subtropical mesothermic with an average annual temperature of $22{ }^{\circ} \mathrm{C}$, and a hot rainy summer season (MARONE et al., 2004). Data from the Hydrology Department (DHID/DPCA/Paraná Waters Institute) indicated that during the study period the mean annual precipitation was around $1800 \mathrm{~mm}$, higher rainfall occurring during the summer. The annual cycle can be described as the occurrence of a rainy period corresponding to spring and summer, and a dry season with low precipitation during autumn and winter (MARONE et al., 2004).

Sampling and Analysis

Twelve sampling campaigns were undertaken between October 2001 and August 2002 in order to determine the Secchi depth and the following variables of bottom and surface waters: temperature, salinity, inorganic dissolved nutrients (nitrate, nitrite, ammonium, phosphate and silicate), $\mathrm{pH}, \mathrm{CO}_{2}$ saturation (through alkalinity measurements), dissolved oxygen, chlorophyll- $a$ and suspended particulate matter. Spring and neap tidal situations were sampled monthly at twelve stations distributed throughout the bay. Temperature, salinity and $\mathrm{pH}$ were measured in situ, while oxygen samples were prepared following the Winkler methodology. The water samples for nutrient, chlorophyll, TN, TP and suspended particulate matter analysis were taken with a Niskin bottle and kept cold until processing and filtration (GF/F fiber glass Whatman filters). Sampling dates and their respective tidal situations are shown in Table 1. Methodologies for analysis and determinations of selected variables are listed in Table 2 . 


\section{Results}

Seasonal Periods

Precipitation rates were analyzed in order to investigate the seasonal patterns and the accumulated rainfall on the seven days before the sampling campaigns. They indicated the occurrence of the same two seasonal periods (Fig. 2) as have also been described for Paranaguá Bay (MARONE et al., 2005). Maximal accumulated precipitation, reaching around $110 \mathrm{~mm}$, was recorded before the sampling campaigns of October 2001, while periods of drought were observed in June and August 2002.

The seasonality of the rainy and dry periods was analyzed by the $t$-test (Tab. 3), aggregating both bottom and surface layers. The increase of around 3 PSU in the salinity, due to the lower freshwater input in the dry season, was followed by the increase of around $0.5 \mathrm{~m}$ of Secchi depth, 0.2 units of $\mathrm{pH}$ and 0.8 $\mathrm{mg} \cdot \mathrm{dm}^{-3}$ of dissolved oxygen. The higher average temperatures of $25{ }^{\circ} \mathrm{C}$ during the rainy season occurred with an increase of around $30 \%$ in $\mathrm{CO}_{2}$ saturation, and $15 \%$ of silicate concentrations. Freshwater discharge is related to inorganic nutrient overloading (MACHADO et al., 1997; WHITE et al., 2004), but the opposite was observed in Guaratuba Bay. Although no significant differences were observed in the chlorophyll- $a$ concentrations, higher phytoplanktonic biomass was observed in the rainy period. The chlorophyll- $a$ data of this study must be considered with care, because the information representing the dry season was only obtained during the April/2002 sampling. All the other surveys undertaken during the dry period lack phytoplanktonic data, which may lead to errors of interpretation.

The results of the remaining variables were, therefore, grouped by the seasonal period and presented as the averages between the measurements performed during the rainy (October to March) and the dry (April to August) seasons.

\section{Physical setting: Temperature and Salinity}

According to the salinity gradients (Fig. 3a), the system was divided spatially into three compartments. Salinity was significantly different $(t-$ test, p-value $<0.05$ ) between the compartments of the estuary that were arbitrarily named as inner section (IS), middle section (MS) and lower section (LS) (see Fig. 1). Average salinity ranged between 1 during the rainy season and 4 during the dry season in IS, from 12 to 17 in MS and 23 to 26 in LS, respectively. At stations 11 and 12, grouped into the inner section of the bay, zero salinity was predominant leading to the characterization of a freshwater dominated zone. Moreover, salinity stratification was permanently observed over the middle and lower sections, where bottom salinities were significantly different, and around 4 PSU higher than the values measured in the surface layers.

The inner section presented permanently colder waters, with a mean of $20.9{ }^{\circ} \mathrm{C}$ in the dry season, while the average maximum of $25.7^{\circ} \mathrm{C}$ was observed in the lower section during the rainy period (Fig. 3b). Average temperatures were up to $25^{\circ} \mathrm{C}$ in the rainy season throughout the estuary, while they stood at around $22^{\circ} \mathrm{C}$ in the dry period.

\section{Inorganic Nutrients}

DIN concentrations (Fig. 4a) were by far higher in the inner section, reaching average concentrations of around 7 and $10 \mu \mathrm{M}$ in the rainy and dry seasons, respectively, while the average concentrations ranged from around 2 to $4 \mu \mathrm{M}$ in the middle and lower sections. Nitrate (Fig. 4b) seemed to regulate the fluctuations of dissolved nitrogen because it represented the major fraction of DIN, especially in the inner section. In this area, around $75 \%$ of DIN derived from nitrate, which presented the highest average concentration of around $7.7 \mu \mathrm{mol} \cdot \mathrm{dm}^{-3}$ during the dry season. Locally depleted patches (nitrate concentrations below the detection limit) were observed at some sampling stations in LS during the rainy season, indicating that primary production was probably limited by nitrogen in this region. Even though the ammonium concentrations (Fig. 4c) were higher than the nitrate levels during the dry season in the middle and lower sections, the highest average concentration of $2.7 \mu \mathrm{mol} \cdot \mathrm{dm}^{-3}$ was also observed in IS during the dry season. Nitrite levels (Fig. 4d) were higher in the inner section, but a decrease in this nitrogen compound was observed in the dry season in this area. Average DIP (Fig. 4e) concentrations ranged between low values of 0.22 and $0.41 \mu \mathrm{mol} \cdot \mathrm{dm}^{-3}$ in Guaratuba Bay. A pronounced increase in DIP, possibly due to the lower biological uptake to be expected during this season (autumn/winter), was observed in LS during the dry period.

The molar ratio DIN:DIP was higher in the inner section (Fig. 4f) because of permanently higher DIN concentrations. DIN enrichment related to land runoff, especially of nitrate, was reflected in a decreasing seaward gradient of the DIN:DIP ratio, with average values of from 7.3 to $12.5,11.0$ to 19.5 and 25.4 to 51.5 in the lower, middle and inner sections, respectively. This pattern was also verified in the Paranaguá and Laranjeiras bays (MACHADO et al., 1997).

Silicate concentrations (Fig. 4g) varied between 10 and $150 \mu \mathrm{m}$ along the bay and were considered low as compared with those of other systems (KNOPPERS et al., 1999a; 1999b; SOUZA; 
KNOPPERS, 2000). Higher silicate concentrations were observed in the upstream and central region with a salinity gradient of between 0 and 5 , decreasing linearly to the system outlet.

Biological Interactions: $\mathrm{pH}, \mathrm{CO}_{2}$ Saturation, Dissolved oxygen, Chlorophyll-a, Suspended particulate matter and Water transparency

The behavior of the $\mathrm{pH}$ was observed (Fig. 5a): the highest average values in LS reached 8.04, while the lowest average of 6.4 was registered in IS. Higher $\mathrm{pH}$ was observed in all the sections during the dry period together with higher salinities. High $\mathrm{CO}_{2}$ saturation (Fig. 5b) levels of over $200 \%$ were permanently observed in Guaratuba Bay, with maxima over $1500 \%$ registered in IS during the rainy season (saturation determined through alkalinity measurements). The relative balance of carbon dioxide species is controlled by $\mathrm{pH}$ and allows the identification of autotrophic or heterotrophic conditions (WHITFIELD; TURNER, 1986; DAY JR, 1989; CARMOUZE, 1994). Guaratuba Bay presented permanently high levels of $\mathrm{CO}_{2}$ saturation throughout the study period, which indicates the predominance of net heterotrophy, as observed in Paranaguá Bay, located $40 \mathrm{~km}$ from the study site. This pattern differs from that of Saquarema Lagoon (RJ), where autotrophy was observed during summer and heterotrophy only during winter (CARMOUZE, 1994).

Dissolved oxygen average levels throughout Guaratuba bay were over $5.5 \mathrm{mg} \cdot \mathrm{dm}^{-3}$ (Fig. 5c) Higher levels were recorded in the dry period and in the lower section, which also registered the lowest concentration observed. The lowest concentration of $3.70 \mathrm{mg} \cdot \mathrm{dm}^{-3}$ was measured in the bottom waters of station 6 , located in a channel between mangrove forests, while the highest of $10.73 \mathrm{mg} \cdot \mathrm{dm}^{-3}$ was recorded in the surface layer at station 1 . Whereas the lower areas of estuaries have higher oxygenation rates due to waves, winds and turbulence, the inner areas and the mangrove channels have lower levels related to higher decomposition rates and less water movement, as verified also for the Baixada Santista (BRAGA et al., 2000).

Chlorophyll-a concentrations (Fig. 5d), considered a phytoplankton biomass indicator, were higher in the bottom layers and in the middle section of the estuary, with the maximal average concentration of $15 \mu \mathrm{g} \cdot \mathrm{dm}^{-3}$ in this area. Lower phytoplanktonic biomass was observed in the lower and inner sections, ranging between 7 and $9 \mu \mathrm{g} \cdot \mathrm{dm}^{-3}$ and 1 and $5 \mu \mathrm{g} \cdot \mathrm{dm}^{-3}$, respectively. In general, higher phytoplanktonic biomass was observed during the rainy warmer season, except for the surface layers of the middle section where higher chlorophyll- $a$ concentrations were observed in the dry period. It is important to emphasize that the lack of appropriate chlorophyll data for the dry season may lead to misinterpretations.

Along with the higher phytoplanktonic biomass, the middle sections presented less water transparency than the other sections (Fig. 5e), ranging from $1.75 \mathrm{~m}$ in LS during the dry season to $0.88 \mathrm{~m}$ during the rainy season. The seasonal pattern of increasing water transparency developing with decreasing suspended particulate matter was not observed on the spatial scale because the higher Secchi depths detected in the lower section occurred also with the highest suspended particulate matter concentrations (Fig. 5f). This unexpected behavior of a greater amount of suspended matter occurring together with high water transparency can be explained by the predominance of suspended coarse particles or simply and most likely by analytical errors.

\section{Astronomical Tides}

The $t$-test for independent samples was applied and the results for the significant $(p<0.05)$ differences between spring and neap tides are presented in Table 4. It is important to mention that precipitation can influence the interpretation of the effects of the astronomical tides on the fluctuation of the water properties. Even though no significant difference was observed between the accumulated rainfall before the tidal phases, higher precipitation was found before spring tides $(55.9 \mathrm{~mm})$ than the levels recorded before neap tides (31.4 mm).

Nitrogen and phosphorus concentrations are affected by tidal phase, as well as water transparency, particulate matter and chlorophyll concentrations, with an average difference of around $22 \%$ for these parameters between spring and neap tides. The magnitude of increased nitrogen content $(25 \%)$ was similar to the decrease of chlorophyll concentrations (24\%) during neap tides. This might indicate that DIN concentrations are regulated by phytoplanktonic growth. An unexpected pattern was found in the increase of water transparency $(1.42 \mathrm{~m})$ and particulate suspended matter $\left(45 \mathrm{mg} \cdot \mathrm{dm}^{-3}\right)$ during neap tides, which might be a result of either the predominance of coarse particles or analytical errors. Still, the distribution of DIN and silicate concentration along the Guaratuba Bay indicated that freshwater input is the main source of these compounds, whereas higher DIP concentrations in the lower sections of the bay during the dry season can be related to the input from the ocean. It seems that the system is more dominated by the tidal intrusion during neap tides, while the freshwater plume seems to spread along the bay during spring tides also because of higher accumulated precipitation. Although the observed differences in the salinity were not significant, a slightly lower salinity 
was observed during spring tides occurring together with the higher precipitation rates.

\section{Trophic Status Thresholds}

In order to present a trophic state evaluation of the estuarine waters of In Guaratuba Bay, six variables were compared to eutrophication thresholds (Table 5). The $\mathrm{CO}_{2}$ saturation levels under $100 \%$ are considered indicators of predominant autotrophy, while over-saturation occurs due to the predominance of heterotrophy (CARMOUZE, 1994). Guaratuba Bay presented a mainly heterotrophic metabolism with very high saturation maxima especially in the inner section of the estuary. Bricker et al. (2003) present thresholds for the trophic status regarding chlorophyll$a$, dissolved oxygen and nutrient concentrations, and for water transparency. The methodology considers the maximum values in a precautionary approach, but the mean values are also presented. The mean trophic status in Guaratuba Bay (considering the average values) may be regarded as intermediate and thus corresponding to a mesotrophic condition, because the majority of water turbidity and chlorophyll concentrations fall into the medium category, though low in relation to mean lower nutrient concentrations, there being no indication of biological stress from oxygen levels under $5 \mathrm{mg} \cdot \mathrm{dm}^{-3}$. On the other hand, when the maxima are considered, a 'worse' trophic status, leading to eutrophic conditions, is indicated. Minimal water transparency indicating the occurrence of 'dark' waters is frequent in Guaratuba Bay, as well as nutrient concentrations around the 'medium' class and the occurrence of biological stress with lower dissolved oxygen levels. Higher chlorophyll concentrations are also found, reaching high levels of around $30 \mu \mathrm{g} \cdot \mathrm{dm}^{-3}$.

The predominance of heterotrophy in the estuary may cause the occurrence of low oxygen patches, leading to biological stress in extreme situations. Moreover, the pressure of increasing nutrient concentrations can also be related to extreme situations that might not happen simultaneously with increasing chlorophyll- $a$. The increment of primary production, indicated by the increase of phytoplanktonic biomass occurring during the rainy period, was followed by a decrease in nutrient concentrations, which were however higher during the dry season. Therefore, the susceptibility to eutrophication of Guaratuba Bay, indicated by the variables presented above, can be considered from low to medium, i.e. oligo- to mesotrophic, because the occurrence of high concentrations of nutrients and low levels of dissolved oxygen take place in the dry period, while higher chlorophyll- $a$ concentrations are observed during the rainy season.
Besides, the great variation in the variables measured demonstrates that water quality in Guaratuba Bay shows substantial oscillations on short space and time scales. Considering the CONAMA 357/05 resolution (MMA, 2005), environmental resolution for classifying water bodies related to human use, the values of the variables $\mathrm{pH}$, nitrate, nitrite and ammonium fall within the thresholds for the Class 1 brackish waters. This class guarantees the use of water for primary contact recreation (bathing, swimming), protection of water communities, aquaculture and fisheries, but demands the measurements of other parameters such as heavy metals and organic compounds. In conclusion, based on the parameters presented in this study, the water quality in Guaratuba Bay permits the utilization of the estuary for activities such as aquaculture and fisheries, but more information regarding other pollutants is still needed.

\section{Discussion}

Based on the physical-chemical information, a summary of the main characteristics of the three compartments of Guaratuba Bay can be presented: 1 . The inner section is characterized by river influence, presenting shallower depths and lower salinity, $\mathrm{pH}$, chlorophyll and dissolved oxygen concentrations, and elevated $\mathrm{CO}_{2}$ saturation; phytoplanktonic growth may be limited by the salinity range and lower DIP concentrations; 2 . The middle section is characterized by a mixing zone with higher turbidity and chlorophyll- $a$ concentrations, medium concentrations of DIN and dissolved oxygen; higher primary production can be related to improved conditions of nutrient supply and salinity ranges; 3 . The lower section presents mainly marine influence with greater depths and lower dissolved $\mathrm{CO}_{2}$ and DIN concentrations. Lower chlorophyll concentrations are observed due to higher hydrodynamics and, possibly, limitation by DIN.

The metabolism of Guaratuba Bay seems to be mostly heterotrophic as a result of presenting $\mathrm{CO}_{2}$ over-saturation, i.e. respiration processes outweigh production processes. Excess of $\mathrm{CO}_{2}$ in riverine freshwater results from interaction between land sources (soil, rocks, riverine processes and gas exchanges), mainly where the runoff of surface soils takes place (ABRIL et al., 2000). Higher $\mathrm{CO}_{2}$ saturation levels in the inner section may be a consequence of higher oxygen consumption and, respectively, higher $\mathrm{CO}_{2}$ production due to anaerobic processes. Moreover, the facts that shallow water areas can be enriched with organic matter from land runoff and that nitrification transforms bicarbonate into $\mathrm{CO}_{2}$ in the same order as oxygen consumption should be taken into consideration. For that reason, $\mathrm{CO}_{2}$ saturation in Guaratuba Bay probably results from the 
interaction between freshwater input, $\mathrm{pH}$, salinity, primary production and mineralization processes, although the quantitative role of the interaction processes are unknown.

In general, dissolved inorganic nutrient concentrations were low in comparison with other systems related to eutrophication problems (FERREIRA, 2000; CLOERN, 2001). These results are not, however, sufficient for the identification of anthropogenic eutrophication. Ammonium concentrations, as an indicator of sewage pollution, were similar all around the bay and are not a clear indication of waste water discharge in this case. Ammonium concentrations were lower than those observed in areas related to anthropogenic pollution in Paranaguá Bay, such as those around the harbour and Paranaguá City (MIZERKOWSKI; MACHADO, 2005). Moreover, the pool of silicate, which ocurred in concentrations around those described for other rivers and estuaries in Brazil (KNOPPERS et al., 1999a; SOUZA; KNOPPERS, 2000; MARONE et al., 2005), can be incremented by the increase of water residence time and the dissolution of particulate silicate in the water-sediment interface, indicated by higher concentrations in the dry period and during neap tides (ITTEKKOT et al., 2000).

The spatial dynamics of water quality seem to be determined by inorganic and/or organic material input associated with freshwater discharge and/or tidal phase variations (ebb and flood tides), rather than by astronomical tides (spring and neap cycles). Furthermore, lateral input of material from marginal areas seems to be very important for the system's dynamics, mostly by tidal intrusion pathways (north margin) and ebb tide flux (south margin). The lowest Secchi depth observed in the middle section can be attributed to this lateral input from mangrove areas especially from the north margin of the system, which is more densely occupied by mangrove swamps than the southern margin. The water circulation system of Guaratuba Bay may be responsible for this geomorphological configuration because tidal intrusion occurs mainly along the northern margin, while ebb tidal currents (together with river flushing) are stronger on the southern margins (MARONE et al., 2004). The pattern is corroborated by the bottom sediment distribution of the Guaratuba estuarine system. The settling rate of fine sediments along the northern margin is of the same order of magnitude as the coarse sedimentation on the southern margin (ZEM et al., 2005). Lateral input may be an important source of material for the system, influencing light penetration in the water column and also other physico-chemical variables.

Vertical stratification in Guaratuba Bay is more evident during neap tides and lower river discharge situations, when the baroclinic component of pressure gradient forcing is intensified (MARONE et al., 2004). However, during spring and/or higher river discharge, higher turbulent diffusion results in better mixing in the water column. No clear pattern could be identified which enabled a distinction to be made between spring and neap tides and their influence on the parameters measured. In order for such a distinction to be made, a fixed sampling point should be established with high frequency monitoring.

The division of Guaratuba Bay into compartments could be better described during the rainy season. Horizontal stratification due to higher freshwater discharge resulted in the fluvial dominance in the IS. The other sections seem to be more subject to tidal forces and marine input "diluting" fluvial input. MS differs from LS because of the greater influence of material drained from the marginal areas, which can be nutrient enriched and provide better conditions for phytoplanktonic growth. During the dry season, horizontal stratification is not so pronounced, which means that tidal forces may be dominant in promoting water mixing. Therefore, continental drainage and the freshwater input may be controlling water quality dynamics during the rainy season, while tidal fluctuations may be the hydrodynamic process controlling the variation in the parameters studied, during the dry season.

Considering that the system is used for several small farms for the cultivation of oysters, which are filter feeders (phytoplanktonic feeders), it is recommended that future studies should estimate primary production rates that, coupled with the results presented in this study, would provide information on the carrying capacity of this estuarine system. Moreover, aquaculture can act in the top-down control of eutrophication as well as in the supply of organic matter (fecal pellets) that can enhance oxygen consumption due to decomposition. Still, this material can represent an extra source of nutrients due to remineralization. Thus, a better characterization of the oyster production in Guaratuba Bay is called for, on which there is as yet little information, as well as regarding the nutrient budgets related to this activity. It is important to highlight that any study of nutrient enrichment processes in coastal ecosystems may be difficult because of the diffuse sources, such as atmospheric deposition in a sub-tropical area and nonpoint discharge of untreated sewage, of those nutrients which make a major contribution to the nutrient input. The sources of the material that contribute to the system may lie far from the estuary, even at the upper limit of the catchment area of the ecosystem. Thus, assessing the trophic status of the system can be considered an important tool, using information such as water renewal time and quantitative criteria based on the various symptoms of eutrophication (BRICKER et al., 1999; 2003), combined with future 
information regarding these point and non-point sources of nutrients in Guaratuba Bay.

\section{ACKNOWLEDGMENTS}

This study was part of the project "Estuarine Dynamics of Guaratuba Bay", funded by the Brazilian Ministry of Science and Technology (MCT) during 2001 and 2002, and by the Institutional Program of Scientific Initiation (PIBic). Special thanks for providing rainfall and river discharge data are due to Mr. Edson Sakae Nagashima of the Hydrology Department (DHID) of the Board of Management and Control of Water Uses (DPCA) of the Paraná Waters Institute.

\section{REFERENCES}

ABRIL, G.; ETCHEBER, H.; BORGES, A. V.; FRANKIGNOULLE, M. Excess atmospheric carbon dioxide transported by river into the Scheldt estuary. Sci de la Terre et des Planets/Earth Planet. Sci., Paris, v. 300., p. 761-768, 2000.

BRAGA, E. S.; BONETTI, C. V. D. H.; BURONE, L.; BONETTI FILHO, J. Eutrophication and bacterial pollution caused by industrial and domestic waters at the Baixada Santista estuarine system - Brazil. Mar. Pollut. Bull., v.40, n.2. p: 165-173, 2000.

BRICKER, S. B.; CLEMENT, C. G.; PIRHALLA, D. E.; ORLANDO, S. P.; FARROW, D. R. G. National Estuarine Eutrophication Assessment: Effects of Nutrient Enrichment in the Nation's Estuaries. Silver Spring, MD: NOAA, National Ocean Service, Special Projects Office and the National Centers for Coastal Ocean Science, 1999. p. 71.

BRICKER, S. B.; FERREIRA, J. G.; SIMAS, T. An integrated methodology for assessment of estuarine trophic status. Ecol Model, v. 169, p. 36-60, 2003.

CARMOUZE, J.P. O Metabolismo dos Ecossistemas Aquáticos: Fundamentos Teóricos, Métodos de Estudo e Análises Químicas. São Paulo: Blücher; FAPESP, $1994.253 \mathrm{p}$.

CHAVES, P.; BOUCHEREAU, J.-L. Use of mangrove habitat for reproductive activity by the fish assemblage in the Guaratuba Bay, Brazil. Oceanol. Acta, v 3, p. 273-280, 2000.

CLOERN, J. E. Our evolving conceptual model of the coastal eutrophication problem. Revision. Mar. Ecol. Progr. Ser., v. 210, p. 223-253., 2001

DAY JR, J. W.; HALL, C. A.; KEMP, W. M.; YÁÑEZARANCIBIA, A. Estuarine Ecology. New York: John Wiley \& Sons, 1989. p. 558.

GRASSHOFF, K.; EHRHARDT, M.; KREMLING, K. (Ed.). Methods of Seawater Analysis. $2^{\text {nd. }}$ ed. Weinheim: Verlag Chemie, 1983. 419 p.

FERREIRA, J. G. Development of an estuarine quality index based on key physical and biogeochemical features. Ocean Coast.Manage., v. 43, p. 99-122, 2000.

ITTEKKOT, V.; HUMBORG, C.; SCHÄFER, P Hydrological alterations and marine biogeochemistry: A silicate issue. Bio Sci., v. 50, p. 776-782, 2000.
KNOPPERS, B.; EKAU, W.; FIGUEIREDO, A. G. The coast and shelf of east and northeast Brazil and material transport. Geo-Mar. Lett., v. 19, n. 3, p. 171-178, 1999a.

KNOPPERS B.; CARMOUZE, J. P.; MOREIRA-TURCQ, P. F. Nutrient dynamics, metabolism and eutrophication of lagoons along the East Fluminense coast, State of Rio de Janeiro, Brazil. In: KNOPPERS, B.; BIDONE, E.D.; ABRÃO, J.J. Environmental Geochemistry of Coastal Lagoon Systems, Rio de Janeiro, Brazil. Rio de Janeiro: Eduff., 1999b. p. 123-154 p. (Serie Geoquímica Ambiental, v. 6)

MACHADO, E.C.; DANIEL, C.B.; BRANDINI, N.; QUEIROZ, R.L.V. Temporal and spatial dynamics of nutrients and particulate suspended matter in Paranaguá Bay, Pr, Brazil. Nerítica, v. 11, p. 15-34, 1997.

MARONE, E.; NOERNBERG, M. A.; DOS SANTOS, I. et al. Hydrodynamics(?) of Guaratuba Bay - PR, Brazil. J. coast. Res., Special Issue , n. 39, 2004.

MARONE, E.; MACHADO, E. C.; LOPES, C. R. M.; SILVA, E. T. Land-ocean fluxes in the Paranaguá Bay Estuarine System. Braz. J. Oceanogr., v. 53, n. 3-4, p. 169-181, 2005.

MMA- Ministério do Meio Ambiente. Conama- Conselho Nacional do Meio Ambiente. Resolução CONAMA 357/2005, 2005.

MIZERKOWSKI, B. D.; MACHADO, E. da C. Análise comparativa da qualidade de água em dois gradientes com diferentes níveis de imapctos antrópicos no Complexo Estuarino da Baía de Paranaguá, sul do Brasil. Oral Presentation. In: CONGRESO LATINOAMERICANO DE CIENCIAS DEL MAR, 11, Viña del Mar, Chile, 2005.

OSPAR. Evaluation of the expected situation of the eutrophication status in the Marine Area following the $50 \%$ reduction target for nutrient inputs. OSPAR Comission - Assessment and Monitoring Series. ISBN 0946956766, 2001.

SOUZA, W. F. L.; KNOPPERS, B. Nutrient and water budgets of a hypersaline coastal lagoon, Araruama Lagoon, Brazil. Loicz Rep. Stud., Texel, v. 15, p. 37 $39,2000$.

STRICKLAND J. L. H.; PARSONS T. R. A Practical Handbook of Seawater Analysis. Bull. Fish Res. Bd Can. $167 \mathrm{p}, 1972$.

WHITE, D. L; PORTER, D. E.; LEWITUS, A. J. (2004) Spatial and temporal analyses of water quality and phytoplankton biomass in an urbanized versus a relatively(?) pristine salt marsh estuary. J. expl mar. Biol. Ecol., v.298, p. 255-273, 2004.

WHITFIELD, M.; TURNER, D. R. The carbon dioxide system in estuaries - An inorganic perspective. Sci. Total Environ., v. 49, p. 235-255, 1986.

ZEM, R. C.; PATCHINEELAM, S. M.; MARONE, E. Morfologia e dinâmica de sedimentos da Baía de Guaratuba-PR. In: CONGRESSO DA ABEQUA (Associação Brasileira de Estudos do Quaternário), 10. Guarapari, ES. Anais..., 2005. Expanded abstract. Available : www.abequa2005.geologia.ufrj.br.

(Manuscript received 20 October 2010; revised 07 August 2011; accepted 20 December 2011) 